\title{
Article
}

Javier García Oliva* and Helen Hall

\section{Trespass to the Person, Human Rights and Ethically Contaminated Food: Freedom of Belief and Bodily Autonomy}

https://doi.org/10.1515/jetl-2019-0102

Abstract: This article explores the specific question of protection which tort law in England and Wales affords to individuals who are victims of ethical spiking (consumption of food contaminated by malicious third parties which is physically harmless, but repugnant to their religion or beliefs), and moves on to analyse the wider implications for the possible evolution of trespass to the person, and the relationship between tort and human rights law in the UK. Although not a comparative piece, it draws on some features of the Spanish paradigm which illustrate significant benefits of developing the law in the English context in the manner suggested.

\section{Introduction}

What private legal redress is available in England and Wales for individuals who discover that a third party has deliberately contaminated their food with a sub-stance which is physically harmless but repugnant to their beliefs? The answer to this question is by no means straightforward, but the conundrum goes to the heart of the values embedded within the legal framework: in essence, what are the fun-damental interests which tort law seeks to protect? As Baez demonstrates, these interests are not static, given that all living legal systems are constantly evolving, but are nevertheless a key element of any sophisticated assessment. ${ }^{1}$ The interests identified as being infringed, and the weight which the juridical system attaches to them, are crucial determiners of the remedies available to individual litigants. This article not only explores a specific question which has not hitherto been ad-

1 BBaez, Tort Law in the USA (2010) 34.

*Corresponding author: Javier García Oliva, Senior Lecturer, The University of Manchester UK, E-Mail: javier.oliva@manchester.ac.uk

Helen Hall, Senior Lecturer, Nottingham Trent University, UK, E-Mail: helen.hall@ntu.ac.uk 
dressed, it also confronts the much wider implications of the problem for tort and human rights law.

There have been a number of high profile cases of ethically contaminated food in Britain, and we shall, therefore, explore the problem in this context. How-ever, a contrasting approach from another jurisdiction will illuminate more clearly some of the more striking features of the English and Welsh paradigm and, for this reason, we will consider certain aspects of the Spanish context as a useful counterpoint. We should stress at the outset that the reflections offered on the Iberian setting are given primarily to draw out features of the English and Welsh system, and the purpose of the piece is not to provide an in depth analysis of the position in Spain nor a comprehensive comparative discussion.

In early 2018 a story broke in the UK via social and mainstream media con-cerning Laura Goodman, a chef who 'spiked' the meal of a vegan customer whom she found 'pious and judgemental'. ${ }^{2}$ There is some dispute as to what actually took place, but despite her subsequent denials, the comment was interpreted to mean that she had covertly introduced animal products into the diner's meal. ${ }^{3}$ A considerable backlash ensued, organised vegan groups coordinated picketing as well as boycott campaigns in relation to the restaurant involved, and the beleaguered Goodman received death threats from outraged strangers. ${ }^{4}$

The anger and fear engendered by the incident is beyond doubt, but it is well trodden ground in England ${ }^{5}$ that injured feelings and mental anguish do not, in and of themselves, generally give rise to a cause of action. ${ }^{6}$ They may often be relevant to the global assessment of damages, but without some additional identifiable interest at play from tort, contract or elsewhere, they will be insufficient to found a claim. ${ }^{7}$ Consequently, in the absence of any harm in the form of personal

2 'Head chef resigns over spiking vegan meal comments' The Guardian 3 January $2018<\mathrm{https}: / / \mathrm{w}$ ww.theguardian.com/lifeandstyle/2018/jan/03/head-chef-gets-death-threats-over-spiking-ve gan-foodclaim>.

3 'Shropshire Chef offers resignation over "spiked vegan" post' BBC News 3 January 2018 http:// www.bbc.co.uk/news/uk-england-shropshire-42552755.

4 'Chef offers to resign after death threats over "spiked a vegan's food" claims' The Telegraph 3 January $2018<$ Lttp://www.telegraph.co.uk/news/2018/01/03/chef-offers-resign-death-threats-spiked-veganfood-claims/ $>$.

5 It should be noted that not all Common Law jurisdictions have held this line. See eg Saadati v Moorhead [2017] 1 Supreme Court Reports (SCR) 543, in which the Supreme Court of Canada allowed psychological injuries to be recognised in the absence of medical evidence.

6 Page v Smith[1996] Appeal Cases (AC) 155; Amlin Corporate Member Ltd v Baby Basics Ltd [2017] England and Wales High Court (EWHC) 2047.

7 Farley v Skinner [2001] United Kingdom House of Lords (UKHL) 49; Shaw v Leigh Day [2017] EWHC 825 Queen's Bench (QB). 
injury or property damage, it at first sight appears difficult to see how the victim of such a spiking incident could claim against the perpetrator, especially since whenever challenged, the UK judiciary have been resolute in holding the line against litigation based on emotional distress. ${ }^{8}$

Furthermore, there are some cogent reasons to support this policy, as Shel-bourn ${ }^{9}$ and Hewson ${ }^{10}$ have both argued. The subjective nature of bruised sensibilities would make constructing appropriate and consistent parameters around such claims an almost insurmountable obstacle. Indeed, as we shall discuss be-low, uncertainty for both claimants and defendants is an issue dogging the Spanish system in relation to this type of damage, since it has for many years adopted a more receptive stance towards emotional injury, or at least 'moral damages', which as a concept is broad enough to include distress falling short of psychiatric injury. ${ }^{11}$ For example, the non-physical element of bullying within a school setting has been found to appropriately fall within moral damage. ${ }^{12}$

However, we would suggest that debates around compensation for injured feelings in England and Wales are actually a distraction from our current enquiry. Critical though such issues are, the primary interests at stake in cases of ethical contamination of food should not be categorised as emotional well-being. Of course, there will ordinarily be negative emotional consequences from the behaviour complained of, but this is usually the case with civil wrongs. For instance, if a claimant is injured due to the defendant's incompetent driving, ${ }^{13}$ or is faced with insinuations of paedophilia all over Twitter, ${ }^{14}$ it is highly likely that this will cause distress, but the fundamental interests with which the legal system is concerned

8 Wainwright v Home Office [2003] UKHL 53 per Lord Scott, para 62; Wong v Parkside Health NHS Trust [2001] England and Wales Court of Appeal (EWCA) 1721.

9 CShelbourn, Comforted but not compensated? Mourners and funeral picketing in English Law (2015) Ecclesiastical Law Journal (ELJ) 283, 288.

10 B Hewson, Privacy claims hit the rocks (2003) 153 New Law Journal (NLJ) $1694 f$.

11 BEspinosa/S Crespo, Los daños morales y su valoración en la responsabilidad médica (1997) 7 Actualidad Civil 143, 158.

12 Audiencia Provincial de Álava (Sección 1aㅡ) Sentencia num. 120/2005 de 27 mayo. For cases of damages for emotional distress not necessarily associated with bodily injury of psychiatric harm in very different contexts, see: Audiencia Provincial de Asturias (Sección 7ª) Sentencia num. 1/2017 de 12 enero (the adverse mental effects of living in damp housing, experienced independently of phy-sical impact); or Audiencia Provincial de Jaén (Sección 1록 Sentencia num. 102/2015 de 9 marzo and Tribunal Supremo (Sala de lo Civil) Sentencia de 26 noviembre 1985 (emotional maltreatment be-tween spouses).

13 Nettleship v Weston [1971] 2 QB 691.

14 McAlpine v Bercow [2013] EWHC 1342 (QB). 
in these cases are physical integrity and protection from unjust reputational da-mage respectively.

Likewise, we would suggest that here there are two underlying interests at stake in claims about ethical contamination of food:1) religious and ideological freedom; and 2) bodily autonomy.

Our keystone question is whether the law of tort in England and Wales effec-tively defends these twin interests in this very specific context. This enquiry is particularly important since, as we shall explore, both of them are indisputably recognised by the European Convention on Human Rights (ECHR) and Strasburg case law.

We leave aside questions of contract, as in many instances there will be no contractual relationship between the victim and the perpetrator, and in any case, the protection of fundamental rights should not be contingent upon private agree-ments. ${ }^{15}$ In the restaurant scenario, it could be that another diner in the party had paid for the meal, and equally, a person eating in public might fall prey to the malice of a stranger. Furthermore, unfortunately, both Anti-Semitic and Islamo-phobic incidents are rising in the $\mathrm{UK},{ }^{16}$ with the use of porcine products a common tactic to cause offence and, disturbingly, one which some far-right groups are even willing to defend. ${ }^{17}$ As a result, it does not require a great leap of imagination to envisage someone in religiously distinctive dress being targeted, and although our study will focus on veganism, given that this was the context in which the issue presented, it should be borne in mind that the discussion has implications for other groups, some of whom are particularly vulnerable at present.

We shall begin by considering what possible avenues for redress a victim of such an incident might have at present in tort, and if these are not wholly satisfactory, whether and how the legal system might bridge any gap. In respect of the first exercise, we shall carry out an analysis of Bhamra $v$ Dubb, ${ }^{18} 21$ st century litigation raising distinct but related issues, as it concerned personal injury

15 There is an interesting discussion to be had about how the Goodman case might have played out in terms of an action for breach of contract, particularly in relation to assessment of damages, but that is outside the scope of our current investigation.

16 UK Government Official Statistics, Hate Crime England and Wales 2016-2017, 17 October 2017 <https://www.gov.uk/government/statistics/hate-crime-england-and-wales-2016-to-2017>; 'Hate crime surged in England and Wales after terrorist attacks' The Guardian 17 October $2017<$ https:// www.theguardian.com/uk-news/2017/oct/17/hate-soars-in-england-and-wales>.

17 'Violent far-right protesters over "outrageous" sentence handed to man who left bacon sand-wich outside mosque', Evening Standard 4 March $2017<$ https://www.standard.co.uk/news/uk/vi olentfarright-protests-over-outrageous-sentence-handed-to-man-who-left-bacon-sandwich-out sidea3481771.html>.

18 Bhamra v Dubb (t/a Lucky Caterers) [2010] EWCACiv 13. 
caused by violation of a religious diet. We shall then discuss to what extent the torts of negligence and Wilkinson $v$ Downton ${ }^{19}$ may respectively assist individuals who have unwittingly consumed food which is incompatible with their beliefs. We will next move on to look at academic commentary formulated in light of the horse-meat contamination scandal, as well as a range of causes of action which were suggested in response, whilst highlighting the potential problems of each. At that stage we shall propose trespass to the person as a possible alternative and, for obvious reasons, we will focus our attention on the two apparent complicating factors with this approach: indirect application of force and the question of intention.

Then moving on to the second limb of our analysis, we will look further at the relevance of human rights law in this context, beginning with Convention rights, in particular those enshrined in arts 8 and 9, before looking at Common Law rights in this setting. We will also assess what impact this human rights backdrop might have on the possibility of applying trespass to the person in these situations. We shall also consider the related, but distinct question, of what the suit-ability of trespass says about the values embedded in the English and Welsh sys-tem. It is here that the comparison with Spain will be especially instructive in drawing out the way in which interests are recognised and prioritised by the juridical system.

\section{Avenues in tort}

A reasonable starting point in assessing how a court might deal with this kind of spiking incident is an assessment of the way in which English law has previously responded to situations with a similar factual paradigm. What does existing case law have to tell us about ethical contaminants in food?

\section{A Bhamra v Dubb (t/a Lucky Caterers) - Personal injury and the violation of religious and ethical diets}

It must be acknowledged at the outset that Bhamra $v$ Dubb differs, to an extent, from an incident of deliberate spiking, as the case did not involve any intention to cause distress (or perhaps even to violate dietary requirements) and, as we shall discuss, intention on the part of the perpetrator is an important consideration.

19 Wilkinson v Downton [1897] EWHC 1 (QB). 
However, it is an instructive 21st century British case involving food contaminated with animal products, contrary to religious principles. A guest attending a Sikh wedding had a known allergy to eggs, but because some branches of Sikhism forbid the consumption of eggs, he assumed that he could safely eat all of the food provided at the celebration. ${ }^{20}$ Regrettably, Lucky Caterers served a dish of ras malai which had in fact been made with egg. The claimant suffered anaphylactic shock and died.

Both the judge at first instance and the Court of Appeal held the defendant liable in negligence. The Court of Appeal concluded that there was no general requirement incumbent upon professional caterers to warn customers that food products might contain egg, even though it was obviously not disputed that a certain percentage of the population are known to suffer from egg allergies. Nevertheless, the defendant was under a duty to take reasonable care to refrain from serving egg in order to avoid offending against Sikh principles. Precisely for this reason, wedding guests were entitled to expect the food provided to be free from eggs, and the defendant was liable for any harm which ensued from acting on the basis of that expectation.

\section{B Tort of negligence}

Commentators applauded the conclusion reached by the court, although had a mixed response to its underlying reasoning. As O'Sullivan ${ }^{21}$ observed, the factual paradigm in many respects mirrored Donoghue $v$ Stevenson, ${ }^{22}$ the wellspring from which the modern tort of negligence flows. In both cases, the claimant suffered in-jury from a food product bought by a third party, and therefore could not seek a contractual remedy. A key distinction, however, was that Mrs Donoghue asserted that she had drunk ginger beer laced with rotting snail, which would reasonably foresee-ably do harm to anybody's digestion, ${ }^{23}$ whilst in contrast, the claimant in Bhamra $v$ Dubb had eaten a wholesome food which most people consume without ill effects.

O'Sullivan criticised the Court of Appeal for asserting that the defendant had a duty of care to avoid offending against religious principles, and stressed that this kind of duty is simply not recognised in negligence. ${ }^{24}$ The key point for this

20 A Singh Mandair, Sikhism A Guide for The Perplexed (2013)171-175.

21 JO'Sullivan, From Egg to Snail: Duty of Care, Fault and Food Allergies (2010) Cambridge Law Journal (CLJ) 435.

22 Donoghue v Stevenson [1932] UKHL 100.

23 J Conn, Gingerlore: The Legends of Donoghue v Stevenson (2013) 3 Juridical Review 265-285.

24 See Sullivan (fn 21) 435, 437. 
commentator was that the defendant had led wedding guests to believe that the food would be egg-free, and it was reasonably foreseeable that individuals with allergies would relax their usual vigilance. There was effectively a representation that the food would not contain certain ingredients, when in fact it did so, with tragic consequences. This was not a case of accidental contamination in a kitchen, but agreeing to provide food which conformed to certain characteristics, and failing to do this.

In contrast to O'Sullivan, Keren-Paz ${ }^{25}$ regarded the existence of a duty of care to avoid offending religious beliefs as a sound proposition, but did not deem it to be central to the case at hand. In his view, the issue was that even though the defendant understood that the menu choices were motivated by religious, rather than health considerations, this knowledge did not negate the fact that physical harm was a foreseeable consequence of failing to comply with the agreed con-straints. ${ }^{26}$

Sometimes individuals have mixed motivations for adopting a particular diet or lifestyle, and Keren-Paz gave the example of a vegetarian observant Jew having two different reasons to avoid McDonalds chips cooked in beef fat; ${ }^{27}$ in the real world, people rely on information to fulfil more than one purpose. Ultimately, in his analysis 'the avoidance of allergy risk is an inevitable by-product of adhering to religious dietary restrictions, and therefore, a physical injury falls within the scope of risk which made the serving of eggs a breach of duty'. ${ }^{28}$

When the arguments are distilled down, the essential point for present purposes remains the same. If religious or ethical standards are assured, and thus generate a reasonable expectation that food will be free from ingredients, then its supplier will be liable if the forbidden ingredients are present, and in fact cause harm. This is in harmony with the basic principles of negligence and is undoubtedly correct. If $\mathrm{X}$ informs $\mathrm{Y}$ that a situation is safe, when it is in fact dangerous, and Y suffers harm from reasonably relying on $\mathrm{X}$, he will have an action in tort for the damage caused. ${ }^{29}$ If a claimant was induced to eat cheese made from cow's milk by a false assurance that it was vegan, and suffered a reaction caused by a lactose allergy, then Bhamra $\vee$ Dubb makes it clear that a claim for personal injury could be brought. Furthermore, if the knowledge that they had consumed dairy

25 TKeren-Paz, Liability for Consequences, Duty of Care and the Limited Relevance of Specific Reliance: New Insights on Bhamra v Dubb (2016) Professional Negligence 50.

26 Keren-Paz (2016) Professional Negligence 64.

27 Keren-Paz (2016) Professional Negligence 65.

28 Keren-Paz (2016) Professional Negligence 66.

29 P Charlish, The Astrid Andersen Case (2004) 4 International Sports Law Review 85. 
damaged the diner's mental health, there would be the theoretical possibility of a claim for this hurt.

It is has long been uncontroversial that psychiatric harm is a recognised cate-gory of personal injury, provided that it is a type which a doctor can objectively assess and verify (the claimant must establish a recognised mental illness, as emotional distress alone will always be inadequate). ${ }^{30}$ Nevertheless, as the work of commentators like Teff shows, the courts are vigilant in monitoring any potential widening of the ambit of such litigation. ${ }^{31}$ A restrictive approach towards duty of care, as well as other elements of the tort, has been maintained in this context.

Consequently, an action for negligence would in principle be possible if a vegan was tricked into consuming an animal product and suffered clinical psychiatric harm as a result. However, in practical terms, the obstacles would be formidable: it would not be easy to establish a relevant duty of care, to demonstrate that the risk of harm was foreseeable, or to show that there was causation be-tween spiking of the food and the mental illness which the claimant experienced. As Jones ${ }^{32}$ argues, establishing causation with psychiatric injury can be an uphill struggle, and Kennedy ${ }^{33}$ is correct to observe that differing scientific and clinical opinions compound the challenges faced by the courts in adjudicating on such matters.

\section{Wilkinson v Downton}

Given that negligence would not be an easy claim, are there any alternative routes? There is a long history of cases involving nervous shock from ill-judged practical jokes, even where these have no physical element. In Wilkinson $v$ Down-ton the defendant told Mrs Wilkinson that her husband had had a horrible accident and suffered two broken legs. Apparently, he thought that this would be funny. Mrs Wilkinson experienced a dramatic and severe reaction which incapacitated her and required medical treatment. An action on the case ${ }^{34}$ was success-

30 See eg Page v Smith [1995] UKHL 7.

31 HTeff, Liability for Negligently Inflicted Psychiatric Harm: Justifications and Boundaries (1998)

57 CLJ 91, 121.

32 MJones, Causation and Psychiatric Damage (2008) 24 Professional Negligence 255, 257.

33 HKennedy, Limits of Psychiatric Evidence in Civil Courts and Tribunals: Science and Sensibility (2004) 10 (1) Medico-Legal Journal of Ireland 16, 19.

34 The branch of tort which played a crucial part in the evolution of the modern law of negligence. See further JBaker, An Introduction to English Legal History (2002) 406-420. 
fully brought, and Wilkinson v Downton claims have survived into the modern law of tort. $^{35}$

However, it should be noted that the remit of such actions is very carefully guarded. In Rhodes v OPO, ${ }^{36}$ the majority of the Supreme Court found that there must be no legitimate reason for the words or conduct of the defendant and there must be an intention to cause severe distress. Crucially, mere recklessness about the consequences would not suffice. Furthermore, the harm inflicted must be diagnosable psychiatric injury, and Wilkinson $v$ Downton is emphatically not a vehicle for obtaining compensation for hurt feelings. Nevertheless, in an instance where one party caused a vegan to consume animal products, and then took malicious delight on seeing the anticipated and intended horrified reaction of the victim upon learning what had happened, it is possible to conceive of a claim being brought if the reaction was so severe as to have an impact on the mental health of the victim.

In Rhodes, the Supreme Court was asked to adjudicate on the publication of an autobiographical book which might cause distress to a close relative of its author, and an injunction was being sought. Attempting to use the tort pre-emptively, as a means of preventing conduct, was in itself a new departure, and this novel context had profound implications for freedom of expression. In fairness, such weighty hu-man rights considerations would not apply in the context of a cruel prank being played on an individual vegan, as limiting an author's freedom to publish his or her life story is a very different proposition from allowing a claim against someone who privately fed meat to a vegan for the satisfaction of witnessing their distress. More-over, it is important to stress that Rhodes did not signal the death-knell for Wilkinson $v$ Downton, but merely a refusal to expand it in a particular direction.

The biggest disadvantage to a Wilkinson v Downton claim is that shared with the tort of negligence, which is unsurprising since, as Réaume observes, the two torts are so closely intertwined that some commentators have regarded Wilkinson as sim-ply being part of the development of the modern tort of negligence ${ }^{37}$ (but this is a debate which need not detain us here). The key point is that to bring either action a claimant must show objectively demonstrable personal injury for the purposes of English and Welsh law. The legal system recognises a right to personal safety, ${ }^{38}$ but safety does not equate to freedom from distress: what if the victim has not been injured in body or mind? A physically and mentally hale vegan who had been on the receiving end of a spiking incident could not bring either claim.

35 Wainwright and Another v Home Office [2003] UKHL 53.

36 Rhodes v OPO [2015] UKSC 32.

37 D Réaume, The Role of Intention in the Tort in Wilkinson v Downton, in: J Neyers et al (eds), Emerging Issues in Tort (2007) 533.

38 OPO v Rhodes [2015] UKSC 32, per Baroness Hale 245. 
Furthermore, the underlying rationale behind this line in the sand provides a powerful reason not to attempt to expand Wilkinson $\vee$ Downton any further in this direction. At present a claimant must show objectively verifiable harm, and either an intention to cause such harm, or recklessness as to whether or not it ensued. ${ }^{39}$ (It is probable that the thorny issue of intention will be revisited in future cases in this area, as its scope remains doubtful in relation to recklessness at least). So what alternative avenues are at the disposal of individuals who unwittingly through deception consume food which offends their principles, but does not inflict assessable damage?

\section{Solutions proposed by Weaver}

In a short, but thorough and thought-provoking article, Weaver ${ }^{40}$ put forward a number of possible paths open to individuals who unknowingly consumed horse-meat or pork in the food contamination scandals involving Ikea and other busi-nesses. ${ }^{41} \mathrm{He}$ quite rightly concluded that none of the routes offered a perfect solution in all instances, but it would be useful to reprise and assess his findings.

\section{Deceit}

Establishing the basic building blocks of this tort would be unachievable for most potential claimants. They would need to show that they had been induced by 'fraudulent representations' to consume the meat, and also that they had suffered a 'detriment'. ${ }^{42}$ Again, the law would not recognise feelings of horror, grief, guilt and revulsion as a detriment, real and unpleasant though they might be. The tort of deceit is concerned with the economic consequences of reliance upon duplicitous assertions. ${ }^{43}$ In fact, in Wilkinson v Downton, Wright $\mathbf{J}$ ruled out any possible action based on deceit, which illustrates the point very well. ${ }^{44}$

39 Y Lieu, The Rule in Wilkinson v Downton: Conduct, Intention and Justifiability (2015) 78 (2) Mod-ern Law Review (MLR) 49, 351.

40 MWeaver, The Mane Lane (2013) NLJ 163, 223.

41 'Ikea withdraws all meatballs from UK stores' The Guardian (25/2/2013) <https://www.theguar dian.com/uk/2013/feb/25/horsemeat-scandal-ikea-meatballs-uk>.

42 Derry v Peek [1889] UKHL 1.

43 Smith New Court Securities Ltd v Scrimgeour Vickers (Asset Management) Ltd [1996] UKHL 3 [1997] AC 254 (21 November 1996); Clef Aquitaine SARL v Laporte Materials (Barrow) Ltd [2000] 2 All England Law Reports (All ER) 493.

44 Wilkinson v Downton [1897] EWHC 1 (QB). 


\section{Contract}

Weaver cited Bhamra v Dubb and correctly pointed out that Donoghue v Stevenson was followed in that instance. The rules of privity mean that contract cannot pro-vide a satisfactory remedy on these facts. We would agree with this conclusion, given that allowing a contractual claim here would drive a coach and horses through the Contract Rights of Third Parties Act. The statute makes crystal clear that a third party can only enforce a contract where there is express provision allowing for this or an intention to confer a benefit on that third party. ${ }^{45}$ The doc-trine of privity has been drastically modified, but not abolished, and the courts cannot simply dismantle it because this appears convenient in a given context.

\section{Negligence}

Weaver acknowledged the point that emotional distress on its own is not sufficient to found a claim. As stated above, the issue is unassailable in UK law, as it currently stands. ${ }^{46}$ A secondary potential avenue would be a negligent failure to warn, which Weaver tentatively suggested could be developed from the duty in a medical context for doctors to warn patients fully of the risks of procedures, or face claims in negligence if there is an adverse outcome. ${ }^{47}$ Again, the weaknesses highlighted by Weaver himself are deeply problematic. Firstly, there is the question of the special relationship between doctors and patients which generates a duty of care to give information, and would not ordinarily apply in other contexts. For example, airlines are not obliged to explicitly inform potential passengers of all known risks of air travel when buying a ticket. Secondly, there is the perennial issue that negligence requires demonstrable legal harm for a claim to be successful.

\section{Conventional awards}

Weaver discusses the so called 'wrongful birth' $\operatorname{cases}^{48}$ in which women have conceived as a result of medical negligence (usually failed sterilisation), and given

\footnotetext{
45 Contract Rights of Third Parties Act 1999, secs 1 and 2.

46 See eg White v Chief Constable of South Yorkshire [1998] 3 Weekly Law Reports (WLR) 1509.

47 Chester v Afshar [2004] UKHL 41.

48 See McFarlane v Tayside Health Board [1999] 4 All ER 961 and Rees v Darlington Memorial Hos-pital NHS Trust [2003] 1 AC 309.
} 
birth to healthy children. The House of Lords in McFarlane rejected the idea that a healthy baby should be seen as damage rather than a blessing, although pain and suffering during pregnancy and birth could properly be construed as injury. Nevertheless, the courts have developed the concept of 'conventional awards' to recompense the mother where appropriate for her loss of autonomy in determining her family size (as opposed to the 'damage' of a baby and the cost of the child's upbringing). Weaver put forward the creative side of similar awards being given in this context to recognise the deprivation of autonomy, but again, conventional awards have never been 'free-floating' independent of an orthodox cause of action in tort.

So does this leave the private law larder bare? Arguably not; there is some-thing on the shelf which could provide sustenance for a healthy claim. There is a tort not explored by Weaver, and its application here would be innovative, but by no means counterintuitive. There is, indeed, trespass.

\section{E Trespass to the person}

As we have seen, the fundamental stumbling block in utilising negligence in cases of ethical spiking is the absence of harm. In contrast, as the masterly Tony Weir observed when comparing trespass and negligence: 'The role of the tort of trespass is quite different. Its very function is to protect and vindicate the basic rights of citizens against deliberate, even well-meaning invasion, whether or not any damage is caused'. ${ }^{49}$

Essentially, an 'invasion of basic rights' is precisely what the potential vegan claimant envisaged above would have faced. This distinguished scholar was referring to rights recognised by the Common Law, long before human rights in their modern form had taken shape. Nevertheless, there is of course overlap, as would be expected, given that the Common Law tradition was one of the many streams which fed into the contemporary human rights framework. ${ }^{50}$ As previously stated, Common Law does not compensate for hurt feelings, but the hypothetical vegan claimant here is not in reality complaining first and foremost about the emotional impact of being surreptitiously fed animal produce. Indeed, to analyse the situation in those terms is to risk trivialising it, because what is being complained of is the very tangible, indeed physical, interference with his or her body, and the autonomy to decide what substances should go into it.

49 TWeir, An Introduction to Tort Law (2006) 133.

50 MTugenhat, Liberty Intact: Human Rights in English Law (2017) ch 2. 
Trespass to the person is an ancient element of the legal system, and the lightest of touches is capable of amounting to a battery ${ }^{51}$ if it is not consensual or in the course of ordinary social interaction. ${ }^{52}$ There was at one stage a suggestion that the touching must be 'hostile', ${ }^{53}$ but it is now universally accepted that this is not the case. ${ }^{54}$ As Weir points out, a kiss is a battery if it is unwanted by the recipient, even if the kisser's intent is not hostile. ${ }^{55}$

In this regard, the law remains as it was set out by Blackstone (and had been since long before his time): ${ }^{56}$

The least touching of another's person willfully, or in anger, is a battery; for the law cannot draw the line between degrees of violence, and therefore totally prohibits the first at the lowest stage of it; every man's person being sacred, and no other having a right to meddle with it, in any the slightest manner.

It might be objected that there is no actual touching in this instance, and that the courts have refused to extend the tort of battery to situations which do not involve physical contact. For example, in the famous case of Kaye v Robertson, ${ }^{57}$ the court was not willing to find that flash photography of a patient in hospital constituted battery. However, it is important to note that in that instance, there was no bodily contact with the plaintiff whatsoever, and as Foster argues, the right which Kaye was trying to assert was the right to privacy. He was not concerned with protecting his corporeal integrity or autonomy over his own body but, entirely understandably, did not want photographs taken without his consent whilst he was critically ill to be plastered all over a national newspaper. ${ }^{58}$ In sharp contrast, in the case of the vegan consuming spiked food, the person on the receiving end of the deception physically consumes the animal product. It would seem absurd to assert that a pat on the hand could constitute 'meddling', whereas being caused to involuntarily swallow meat could not. The latter is, without a shadow of a doubt, a far greater bodily invasion.

Nevertheless, it cannot be claimed that the application of battery to the factual paradigm under consideration is wholly straightforward. Two issues in parti-

51 Cole v Turner (1704) 6 Modern Reports (Mod Rep)149.

52 Collins v Wilcock [1984] 3 All ER 374.

53 Wilson v Pringle [1986] 2 All ER 440.

54 See eg Re F [1990] 2 AC 1, per Lord Goff para 73.

55 Weir (fn 49) 134.

56 WBlackstone, Commentaries on the Law of England (1765) Book III 120.

57 Kaye v Robertson [1991] Fleet Street Reports (FSR) 62.

58 S Forster, Say Allo, Allo, Wave Goodbye: Remembering the Decision in Kaye v Robertson (2016)

21 Coventry Law Journal 57. 
cular must be resolved if this mechanism is to provide a solution: firstly, the in-direct application of force in relation to the act of battery, and secondly, the ques-tion of intention on the part of the defendant, coupled with the related matter of consent as far as the claimant is concerned.

\section{Indirect application of force}

Battery has frequently been understood to require the direct application of force. For instance, there is the oft quoted definition from Winfield and Jolowicz: 'the intentional and direct application of force to another person' ${ }^{59}$

However, the concept of directness for these purposes has for centuries been an extremely malleable one, and it has arguably now been transmuted to the point of extinction in criminal law. Not only would it be logical for the law of tort to follow suit in extinguishing it altogether, there is also ample authority to demonstrate that the courts have long been prepared to adopt a flexible understanding of what it means to directly inflict battery.

In Gibbons v Pepper ${ }^{60}$ an action for battery succeeded when the defendant whipped a horse, causing it to bolt and trample the plaintiff. There was no need for any direct physical contact, a principle again affirmed in $R v$ Cotesworth ${ }^{61}$ and Pursell $v$ Horn, ${ }^{62}$ cases in which it was respectively concluded that spitting and throwing boiling water could amount to battery. In addition to the lack of any need for direct physical contact, Gibbons v Pepper also shows that the Common Law does not require there to have been an immediate or inevitable link between the defendant's action and the force which inflicted the battery. An intervening action or agent may cause the unlawful touching, and there is no need to show that the contact was inevitable. In Gibbons, it was obviously not certain that the distressed and abused horse would react exactly as it did and collide with the plaintiff.

59 WRogers, Winfield and Jolowicz on Tort (16th edn 2002) 71.

60 Gibbons v Pepper [1695] 1 Lord Raymond's Kings Bench Reports (Ld Raym) 38. Whilst this con-cerned a procedural debate as to whether action on the case or trespass was the correct form of action, debates about case versus trespass foreshadowed later debates about negligence versus trespass. Furthermore, procedure and substance cannot readily be separated at this period of Eng-lish legal history.

$61 \mathrm{R} v$ Cotesworth (1704) 6 Mod Rep 172; 87 ER 928.

62 Pursell v Horn (1838) 8 Adolphus and Ellis (Ad \& E) 602; 112 ER 966. 
Scott $v$ Shepherd ${ }^{63}$ is even more instructive for these purposes. The defendant in this case threw a firework (a 'serpent' into a covered market, which landed on a very surprised gingerbread seller. In understandable panic, he tossed it onto an-other cakestall, from whence it was flung in horror by a second vendor, only to eventually explode in the unfortunate plaintiff's face. The defendant tried to argue that his initial action in throwing the squib had not injured the plaintiff, and that the serpent had only hit him because it was hurled by a third party. The justices were divided in considering this plea that trespass did not apply because the force was not direct, but the majority ruled that in having instigated a non-consensual game of pass the parcel with a lighted firework, the defendant had directly caused the explosive to strike the plaintiff.

Interestingly, in addition, all of the judges and both counsel were of the view that had the defendant turned loose a mad ox in the market, the people whom it gored would have been able to bring a trespass action. The question in the minds of the justices and serjeants in Scott $v$ Shepherd appears, therefore, to have been one of whether the causation was direct, rather than assessing whether there was a direct physical link. All things considered, it is crucial to emphasise that it has never been the case in either criminal or civil law that the defendant must always, personally, physically apply the unlawful force for trespass to lie.

Furthermore, some rather more recent decisions in the criminal context make it abundantly clear that a battery can take place where the victims are tricked or manipulated into applying the force to themselves. For example, in K v DPP, ${ }^{64}$ a 15 year old schoolboy stole some acid from a chemistry lab and placed it in a hand-drier in the boys' toilets. Afterwards, a fellow pupil attempted to use the hand-drier, the acid sprayed out, burning him and causing permanent facial scar-ring. The defendant was charged and convicted under s 47 of the Offences Against the Person Act 1867, and the fact that he had not directly applied the force did not mean that he was not responsible for its application.

The outcome of DPP $\vee \mathrm{K}$ is unsurprising, as it has long been recognised that setting up a booby trap or engineering a situation in which a victim will run into an object will constitute an application of force for the purposes of battery. In Martin ${ }^{65}$ the defendant turned off the gas-lighting in a theatre, placed an iron bar across the door and shouted 'fire'. In the stampede to escape several people were badly injured, and the court robustly rejected his contention that the law required the force to be applied directly.

63 Scott v Shepherd (1773) 3 Wilson's Kings Bench and Common Pleas Reports 403; 95 ER 1124.

64 DPP $\vee$ K (a minor) [1990] 1 WLR 1067.

$65 \mathrm{R} \vee$ Martin (1881) 8 QB 54. 
Nevertheless, it should not be overlooked that the decision in DPP $\vee \mathrm{K}$ has not escaped academic criticism. Hirst went as far as to suggest that it was decided per incuriam, ${ }^{66}$ although it must be acknowledged that his reasoning in doing so was extremely tenuous. In a nutshell, he argued ${ }^{67}$ that the House of Lords in Wilson ${ }^{68}$ had implicitly affirmed the judgment of the Supreme Court of Victoria in Salisbury

${ }^{69} \mathrm{He}$ then went on to suggest that this decision could potentially be construed as asserting that battery requires the application of direction force. However, Hirst himself accepted that alternative interpretations of Salisbury are possible and that the Australian dictum is not a model of clarity" ${ }^{70}$. Consequently, his claim that DPP v $\mathrm{K}$ was wrongly decided rests on a doubtful interpretation of an ambiguous statement, made obiter, and in authority of merely persuasive status.

Every link in the chain of reasoning is fragile, and it is unsurprising that neither courts nor other authors have been persuaded to follow his analysis. Sjö-

lin, ${ }^{71}$ for instance, not only cites DPP $\vee \mathrm{K}$ with approval, but also observes that the court took a similar stance in Santa-Bermudez. ${ }^{72}$ In this case, the defendant told the police that he had 'no sharps' on his person, which was a lie and the victim suffered a needle-stick injury when she pricked herself on a syringe in his pocket.

Strong parallels can be found between this situation and the vegan restaurant customer. In Santa-Bermudez, the police officer brought her hand into contact with the needle, the physical action was hers and not the motion of the defendant. Nevertheless, in a criminal prosecution for assault occasioning Actual Bodily Harm, it was decided that this did not transfer the burden of responsibility for the physical contact away from the defendant. It was clear that the police woman had

placed her hand where she did due to the strength of the defendant's assurance. ${ }^{73}$ Similarly, in the case of a spiked vegan, the diner would have consumed the food because, and only because, they had been told that it contained no animal pro-ducts. In both senses, the false statement by the defendant would be the trigger for the victim's action, and the non-consensual bodily invasion which ensued. On this basis, the question of directness might be resolved, but this still leaves the

66 MHirst, Assault, Battery and Indirect Violence (1999) Criminal Law Review (Crim L Rev) 557.

67 Hirst (1999) Crim LRev 558.

68 R v Wilson [1984] AC 242.

$69 \mathrm{R} \vee$ Salisbury [1976] Victorian Reports 452, 461.

70 Scott v Shepherd (fn 63) 558.

71 CSjölin, The Need to Kill Off Zombie Law: Indecent Assault, Where it Went Wrong and How to Put It Right (2017) 81 Journal of Criminal Law 50.

72 Santa-Bermudez [2003] EWHC 2980 (Admin).

73 The defendant was convicted by the Magistrates' Court, but appealed successfully to the Crown Court. However, the Director of Public Prosecutions appealed further for a ruling on whether the actus reus had been established, and the High Court made a determination on this point. 
matter of intention. The mind of both the defendant and the claimant are key to the reasoning applied in these cases. In relation to the defendant, we need to address the issue of intention, whilst consent on the part of the claimant is a golden thread which runs through both the case law and our analysis. It is the ability to give or withhold consent which ultimately ensures that bodily autonomy is maintained and protected.

\section{Intention}

Oliphant observes that trespass to the person is one of a family of intentional torts, but the only one actionable per se. ${ }^{74}$ In order to have committed battery, the defendant must have intended to apply the unlawful force, but there is no need for any additional intention to cause harm or offence. As Oliphant astutely observes, this is because of the unique role which trespass to the person has in safe-guarding bodily autonomy ${ }^{75}$ and, due to the special importance of the interest concerned, the bar for intention is set low. The focus is on the right of the claimant, not the wrong of the defendant. Bound up with this is the issue of consent: what was the claimant agreeing to take place in respect of his or her body? If the defendant intentionally strays beyond the bounds of any permission given (ex-press or implied) then the consent will not be operative.

Yet for our purposes, this raises the question of whether bringing ethically contaminated food into the trespass fold would expose too many people to liability. The hypothetical vengeful chef is in a very different position from a conference caterer who places a vegan's name on the wrong list and accidentally serves him or her a lunch containing cheese. Should the latter be liable in trespass if a delegate consumes something he or she would prefer not to touch? Is the lack of any requirement to show malice or an intention to cause harm problematic?

Arguably it would be, were there not a solution already built into the fabric of the tort of battery. As we have seen, everyday social touching will not amount to a battery, and interaction within its bounds will not be tortious unless the defendant knew that the claimant objected to a type of contact which is otherwise generally deemed acceptable. ${ }^{76}$ The dance between intention and consent is quite a subtle one here, and arguably has never been fully drawn out in English law. As high as bodily autonomy is prized, tort cannot protect this interest in ways which unjustly

74 KOliphant, The Structure of Intentional Torts, in: J Neyers et al (eds), Emerging Issues in Tort (2007) 513.

75 Oliphant (fn 74) 529.

76 Collins v Wilcock [1984] 3 All ER 374. 
impose liability on third parties, nor make daily life unmanageable. Balancing the rights of potential defendants and claimants is not straightforward, which is why the interaction between intention and consent is complex.

In concrete terms, jostling by a crowd in a busy station is not battery. Some older authorities explained this on the basis of implied consent, ${ }^{77}$ but following the dicta of Goff LJ in Collins $v$ Willcock the prevailing view is now that there is a general exception which removes routine social interaction from the ambit of tres-pass to the person. ${ }^{78}$ Nevertheless, there is a further layer of complexity here. Where a defendant is fully aware that a specific individual objects to a touch which would ordinarily fall within this general exception then, reasoning from first principles, it is surely the case that an action for battery would lie if a defen-dant intentionally inflicted such touching.

It is true that a hypothetical claimant could not expect to stand in the middle of Oxford Circus tube station during the rush hour and demand to sue everyone who inadvertently brushed or bumped into them, on the basis that they had been yelling 'Don't touch me!' at the time. Clearly, touching of a kind which is unavoidable and essentially unintentional cannot reasonably impose liability on a defendant, and equally, it would be grossly unfair to render a defendant liable for giving a colleague a friendly pat on the shoulder, because the recipient harboured an entirely secret hatred of being touched. Ordinary social interaction as envisaged in Collins v Willcock must, in general terms, be an objective standard of behaviour, but what about the case where the defendant is fully aware that the person in question does not wish to patted? Surely an action must lie here for gratuitous, avoidable and intentional touching, based on the expressed, subjective wishes of the person receiving the touch? Otherwise, no action would lie where a malicious person touched a Muslim or Orthodox Jewish individual of the opposite sex with the intention of causing them distress, or wished to torment someone on the autistic spectrum who loathed physical contact. That conclusion would run counter to the objective of protecting bodily autonomy, and is not demanded in order to safeguard defendants from unjust or onerous burdens.

Of course, it might be argued that this can be explained on the basis of Collins $v$ Willcock, given that deliberately touching someone with the aim of upsetting them is not actually within ordinary social interaction. A mild degree of friendly, non-sexual touching between non-related people is normal in UK culture, but only where it is assumed that it will be welcomed. As reasonable people do not

77 Rawlings v Till (1837) 3. Meeson \& Welsby's Reports (Eng).

78 Collins v Wilcock [1984] 3 All ER 374. 
poke others just to make them miserable, a lack of subjective consent can some-times take behaviour outside of the general exception.

Consequently, in the context of this kind of spiking, intention would not re-quire malice or a desire to harm, but simply a conscious intent to bring the claimant into contact with a substance, knowing that they objected on ethical grounds. If the person providing the food did not know that the recipient objected to it, there would be no trespass. Causing someone to touch a ham roll is not generally outside of the bounds of normal social interaction, but is the specific, knowingly non-consensual nature of the touch which makes the spiking of food unlawful.

However, the converse consideration also applies: a defendant would not be able to rely on the consent of the victim as a defence, if he or she only consented to eat food because they were deceived as to its nature. For example, deception and concealment are now accepted as being capable of rendering sexual activity battery, even though the victim was a willing participant at the time when the act took place. ${ }^{79}$ In short, infecting a partner with a sexually transmitted disease, when they did not consent to this risk, is capable of transforming the sexual con-tact in question into an offence against the person. The deception negated the consent, because the victim had not agreed to have sexual intercourse with a partner known to be HIV positive. Therefore, deception about collateral aspects of the act, as well as the act itself, are sufficient to vitiate consent in this context. Note that as Welsh observes, this has not been characterised as rape, but the infliction of bodily harm. ${ }^{80}$ There are obviously complex social and legal issues concerning the intervention of criminal law in sexual relationships which do not re-late to the current discussion, but the point for present purposes is that deception can render an ostensibly consensual action an assault.

For the sake of completeness, it should be recognised that in the medical context, the UK legal system has consistently resisted characterising a failure to fully disclose risks about a procedure as vitiating consent, rendering the doctor's action trespass, and such claims must be pursued in the realm of negligence in-stead. ${ }^{81}$ As Tavares points out, the recent Court of Appeal decision in Shaw $v$ Ko-vas ${ }^{82}$ not only affirms the conventional wisdom on this issue, but also rejects the use of any human rights based argument to deem consent given without adequate explanation a nullity. ${ }^{83}$ (The litigation concerned a claim brought following heart-

79 R v Dica[2004] 3 ALL ER 593; R v Konzani [2005] EWCACrim 706.

80 LWelsh, Intent to Harm (2017) 181 Justice of the Peace 795.

81 See eg Montgomery v Lanarkshire Health Board [2015] UKSC 11; Shaw v Kovac [2017]

EWCACiv 1028.

82 Shaw v Kovas and University Hospitals of Leicester NHS Trust [2017] 1 WLR 4773.

83 NTavares, Shaw v Kovac (2017) 4 Journal of Personal Injury Law 218. 
surgery on an 86 year old patient, who had not given informed consent and died during the procedure. The court considered this aspect of the case at length and explicitly ruled that no separate award should be given to reflect this deprivation of autonomy). Nevertheless, we would suggest that the professional duty of clinicians to communicate effectively with patients is correctly categorised as a particular area of medical law, and not analogous to the spiked vegan situation. The policy implications of concluding that doctors were committing unlawful assaults on patients if they failed to make adequate professional disclosures would be considerable. The obligation to give full and adequate information is one which should quite properly be regulated by the law of professional negligence, but this is not a debate which we should initiate here.

The key point for our analysis is that the general law of trespass has the potential to furnish a vegan diner with a remedy if they were to discover that their food had been tampered with. Their bodily autonomy would have suffered a violation to which they did not consent, and it is the function of this branch of tort to address this. The issue is not whether any demonstrable harm was caused in the sense of physical or psychiatric injury, but whether the perpetrator's deliberate actions could have caused the claimant to have a physical substance enter his or her body when he or she did not wish for this to happen. Viewed through this lens, the law of trespass appears entirely appropriate.

Having said which, we do acknowledge that using trespass in this way is venturing into new ground. More conservative observers might find the issue of directness in particular to be a stumbling block, arguing that the cases founded upon indirect contact are an aberration (although given the antiquity and established status of some of the authorities, we would strongly dispute the cogency of such a stance). ${ }^{84}$ Therefore, it would be fruitful to carry out further analysis about whether there are any factors in the wider legal framework which might incline judicial thought towards accepting our proposed solution.

\section{Human rights}

One important area to explore in this regard is human rights. As McCorkingdale argues, the current British structure of human rights is complex, but based around 'the twin pillars of Convention and common law rights jurisprudence'. ${ }^{85}$ We would also endorse Wright's contention that these binary streams are not

84 See discussion above.

85 CMcCorkindale, Brexit and Human Rights (2018) 22 Edinburgh Law Review 126. 
fused, despite the obvious and significant influence and interaction between them. ${ }^{86}$ For this reason, we shall consider these aspects of the current framework sequentially, beginning with Convention rights and moving to Common Law rights, although we will of course discuss the impact of the former on the latter.

However, in turning to Convention law rights, we must first address which articles are most likely to be engaged where an individual is tricked into consuming food which is repugnant to their belief system.

\section{A Convention rights}

One right to consider where the violation of religious belief or ethical principle is concerned is undoubtedly art 9, which exists precisely in order to defend freedom of conscience and religion. Not only does it confer an absolute right to hold beliefs upon fundamental matters, it also provides that the right to manifest such beliefs can only be limited in so far as is prescribed by law and necessary in a democratic society. It is now well established that vegan beliefs can attract the shield of art 9, and that the avoidance of animal products is the most obvious manifestation of such beliefs. ${ }^{87}$ However, it is worth pausing to ask whether all vegans would have access to this article.

In a recent family law case concerning a mother who opposed vaccinations for her children, in part on the basis of her vegan ethical views, the court asserted that veganism 'is not a religion, it is a lifestyle' ${ }^{88}$ Furthermore, courts have explicitly acknowledged that ${ }^{89}$ people become vegans for a wide variety of reasons, including health concerns, medical needs, ethical issues and religious convictions. Consequently, there are some doubt as to whether all professed vegans could rely upon art 9, or only those for whom a vegan lifestyle is in a fact a manifestation of a qualifying belief.

The House of Lords in R (Williamson) v Secretary of State for Education and Employment ${ }^{90}$ laid down guidance on the types of beliefs which would qualify for protection under art 9. A requisite level of seriousness and importance must at-tach to them, they must be on a fundamental matter and they must be sufficiently

86 JWright, Tort Law and Human Rights (2017) 308-311.

87 ECtHR Jakobski v Poland, 7.12.2010, no 18429/06, 1974; H v UK (1991) No 18187/91.

$88 \mathrm{C}$ v EF (In the matter of M and N) [2016] England and Wales Family Court (EWFC) 69 (Fam) per Rogers J, para 67.

89 Alpro Ltd v HMRC (2006) West Law 3880346.

$90 \mathrm{R}$ (on the application of Williamson) $v$ Secretary of State for Education and Employment UKHL 15 [2005] 2 AC 246. 
coherent. Nevertheless, the court also acknowledged that religious beliefs in par-ticular did not need to be rational or logical in objective terms, as that is not ne-cessarily always the nature of faith. This is in harmony with the general approach taken by the Strasbourg Court in recognising that the article is engaged, ${ }^{91}$ and also approved by commentators who affirm the inherent inappropriateness of legal frameworks treating religious practice and identity, as phenomena which can be verified or dismissed according to external criteria. ${ }^{92}$

Bearing this in mind, it would appear very difficult to justify regarding nonreligious matters of belief or conscience within the ambit of art 9 as different from religious ones. The text of the article makes no distinction between categories of beliefs, and to demand that non-religious applicants clear a higher hurdle to ac-cess protection would, in itself, be discriminatory. As a result, it is reasonable to assert that non-religiously motivated vegans would not be required to demonstrate that their understanding of veganism could be objectively justified in abstract intellectual terms, in order to qualify for protection. Thus whether a particular vegan chose to consume honey ${ }^{93}$ or feed meat to obligate carnivore pets would not have any bearing on their access to art 9, irrespective of debates within vegan-ism and wider society about the internal coherence of such decisions.

However, Temperman demonstrates that an applicant wishing to rely on art 9 must also be able to assert that the underlying belief is held with sincerity. ${ }^{94}$ The genuineness of a belief is very different from its logic or lucidity, and religious and non-religious beliefs alike must be held in earnest if art 9 is to apply. It is interesting how this may play out in a context like veganism, where some individuals may elect to avoid animal-products on some occasions, but not others. Nevertheless, given that art 9 uncontroversially encompasses the freedom to change religious beliefs, there is no reason to assert that 'part-time' vegans would be excluded from its ambit. ${ }^{95}$ The requirement of genuineness exists to filter out applicants who may be dissimulating for ulterior motives, but not to demand unwavering ideological commitment, as this would undermine the very liberty which it seeks to protect. In terms of interests recognised by the legal framework,

91 See eg ECtHR Dogru v France, 4.12.2008, no 27058/05 and Kervanci v France, 4.12.2008, no 31645/04.

92 RDomingo, God and the Secular Legal System (2016).

93 NSweeney, Bees-at-Law (2017) 312-315. Sweeney explores different philosophical perspectives on the human use of bees and their status as creatures.

94 JTemperman, Freedom of Religion or Belief in Prison ACritical Analysis of the European Court of Human Rights Jurisprudence (2017) 6 Oxford Journal of Law and Religion 48.

95 Re L (Religious Upbringing) [2010] EWHC 2503. 
the freedom is to not simply hold beliefs, but to discard and develop them without adverse consequences.

However, in the recent High Court decision in Re $M,{ }^{96}$ the court appeared to add a further gloss in relation to beliefs passing through the filter of art 9. The appellate court expressed doubts about whether beliefs, which were incompatible with the values of a liberal democratic society, would meet the threshold for pro-tection, ${ }^{97}$ but it should be stressed that the remarks were obiter and by no means unproblematic. In fact, if only views which conform to the values of mainstream society are shielded by art 9 , it is difficult to see how it can be expected to protect vulnerable, and perhaps unpopular, minorities from oppressive or unfavourable treatment. As Rubenstein ${ }^{98}$ argues, $^{2}$ shielding minority groups from majoritarian tyranny is an accepted obligation for a liberal democratic State, and both domes-tic courts and Strasburg have repeatedly recognised the application of art 9 to non-liberal beliefs. ${ }^{99}$ We would not seek to build too much on obiter dicta trans-planted from its original context, and in any case, there is certainly no suggestion that veganism poses a challenge to liberal democratic society, but for present purposes it is important to note this recent and clear judicial message that not all beliefs will be simply waved through the gateway of art 9. Courts will scrutinise the factual context before them, and certainly will reject some attempts at asserting qualifying beliefs, as Jones $v$ UK also demonstrated. ${ }^{100}$

Yet, it remains true that where a positive belief is asserted, courts rarely test its robustness without some tangible reason to either be suspicious, or err on the side of caution. In Vartic v Romania, ${ }^{101}$ the Strasbourg Court was unsympathetic to the State's attempt to assert that a prisoner was simply angling for better food in demanding a special religious diet in conformity with his Buddhist faith, even though it was admitted that his motivation partly related to his health. It is significant that the beliefs subjected to doubt in $\mathrm{Re} \mathrm{M}^{102}$ were being asserted as the

96 Re M (Children) (Contact: Ultra-Orthodox Judaism: Transgender Parent) [2017] EWFC 4; [2017] 4 WLR $20181 \mathrm{R}$.

97 Ibid para 121: '[A] religious belief, practice or observance that was inconsistent with the princi-ple of non-discrimination under that legislation is not compatible with the requirements of our society. If that was so, the belief, practice or observance in question might not achieve the level required for art 9 protection'.

98 A Rubenstein, Unashamed Liberalism: Liberal, Illiberal and Anti-liberal minorities (2017) Public Law (PL) 270.

99 Eweida v United Kingdom [2013] ECHR 37; R (on the application of Ngole) v University of Shef-field [2017] EWHC 2669 (Admin).

100 ECtHR Jones v United Kingdom, 14.1.2014, no 42639/04, ECHR.

101 ECtHR Vartic v Romania (no2), 17.12.2013, no 14150/08.

102 Re M (Children) (Contact: Ultra-Orthodox Judaism: Transgender Parent) [2017] EWFC 4. 
foundation for discriminatory behaviour against a transgender individual and their minor children. Moreover, the context was material to the way in which the court analysed the beliefs at hand and unquestionably a situation involving an adult voluntarily abstaining from animal-products, and harming nobody in the process, would be dramatically different. There is nothing about veganism in general terms which would actively invite exceptional scrutiny from judges.

Even so, there must logically still be some limits in accessing art 9 for vegans motivated by health concerns, rather than ethical ones. Otherwise, parity of treatment would logically demand that individuals who chose to follow diets free from gluten or processed sugar or low in cholesterol could request that this be catered for by public authorities, on the basis of a right to freedom of religion and belief. As discussed below, there may be alternative Convention rights at play in situations like these, but not the one targeted at defending ideological liberty.

Nevertheless, even accepting that the borders of art 9 are not wide enough to encompass all vegans in all circumstances, there is reason to anticipate that the boundaries will be generously interpreted. It is uncontroversial that a very large number of vegans have followed that pathway in deference to deep personal con-victions, and as such entirely properly attract the safeguards of human rights law.

Furthermore, public authorities would do well to take cognisance of this reality, as Fouzder demonstrated in relation to a recent controversy involving an NHS Trust. ${ }^{103}$ An advertisement had been placed for an occupational therapist in an eating disorders service and stated explicitly that any applicants who adopted vegan diets would be excluded from consideration. This was challenged by the International Vegan Rights Alliance, as well as Barbara Bolton, a solicitor and vegan activist. The Trust hastily backtracked and amended the advertisement ${ }^{104}$ significantly, by removing the caveat altogether, rather than attempting to differentiate between various categories of vegans. Bolton correctly observed that the previous advertisement was discriminatory, and that veganism has been consistently recognised as a protected belief for the purposes of international and domestic law. It is evident that in general terms, discrimination against vegans will engage human rights and also fall foul of equality law, ${ }^{105}$ and that even if a sub-category of those adopting a vegan lifestyle may have difficulty accessing the shield of art 9, the default assumption must be that it will be engaged where vegans are concerned.

103 MFouzder, Vegan Challenges Discriminatory Job Ad (2017) 30 Law Society Gazette. 104 Apology after job advert discriminates against vegans, Plant based news, 14 June 2017 <ttp s://www.plantbasednews.org/post/apology-after-job-advert-discriminates-against-vegans $>$. 105 Equality Act 2010, sec 4. Protected characteristics include 'religion and belief'. 
In light of all of this, there is reason to assert that the art 9 rights of vegans are engaged in relation to assuring that their ethical dietary choices are respected whilst eating in public. The same would, of course, be the case in respect of Jews, Hindus, Buddhists, Muslims and any other faith group with doctrinal food restrictions. There is no controversy about the premise that the UK legal framework post 1998 recognises freedom of belief as a fundamental interest demanding protection.

Nevertheless, this is not the only Convention article which has relevance in this context, as there is also the right to private and family life. ${ }^{106}$ As we outlined at the beginning of our analysis, we are also concerned with an individual's interest in bodily autonomy, in deciding what they do or do not wish to consume. Both Strasburg and the domestic courts have consistently taken an expansive approach to art 8 , and the interests which come within its ambit. It is accepted that the right encompasses the freedom to make decisions in a medical context, relating to the treatment of one's own body, ${ }^{107}$ and interference with corporeal autonomy, in the form of temporary detention and forcible touching of the kind involved in the use of police stop and search powers may be sufficient to infringe its terms. ${ }^{108}$ It is, therefore, reasonable to assert that a court would be willing to conclude that causing an individual to consume foodstuffs in opposition to their personal choices would interfere with their right to privacy as bodily invasions are, after all, even more intimate than violation of the home. Moreover, access to art 8 is not dependent upon any qualifying belief or identifiable principle, so applicants would not have to clear hurdles comparable to those set out above in relation to art 9.

Taking the foregoing into account, it can be asserted with confidence that the victims of spiking incidents of the kind under consideration would be able to demonstrate that their arts 8 and 9 rights had been engaged. Furthermore, where Convention rights are interfered with, it is not necessary for an applicant to show that public authorities are responsible for the relevant infringement, because the State has an obligation to ensure that individuals have appropriate legal recourse if their rights are violated or curtailed. ${ }^{109}$ It goes without saying that this does not automatically mean that the rights in question will be vindicated in all cases, as neither art $8^{110}$ nor

106 Art 8 ECHR.

107 ECtHR Pretty v United Kingdom, 27.7.2002, no 2346/02 [2002] ECHR 423; The Northern Ireland Human Rights Commission's Application [2015] Northern Ireland Queen's Bench 96. 108 Gillian and Quinton v UK [2010] ECHR 28.

109 Eweida v United Kingdom [2013] ECHR 37.

110 We have included the full wording of each, as the grounds for limitation are subtly but significantly different. Art 8(2): 'There shall be no interference by a public authority with the exercise of 
art $9^{111}$ confer absolute freedoms, and in fact on many occasions Convention rights must necessarily be balanced against competing rights and societal interests. ${ }^{112}$ However, national authorities must be able to show that an appropriate balancing exercise has been carried out, and it is exceedingly difficult to imagine such an assessment properly concluding that the denial of effective legal protection and re-dress for individuals, when faced with a malicious spiking incident, was in fact a justifiable limitation of their rights. Strikingly, such a stance would serve no obvious benign purpose, and it would actively undermine some of the legitimate societal aims set out in the qualifications contained in arts 8(2) and 9(2) respectively, for ex-ample, advancing public safety, preventing disorder and protecting order.

Bearing all this in mind, there is clear pressure stemming from the Convention to award victims of this type of spiking some potential remedy for their violated interests, in terms of both freedom of belief and bodily autonomy. Having reached this conclusion, we are now bound to ask by what mechanisms the cur-rent English and Welsh framework provides for the practical defence of these rights. In fact, the causes of action which can currently be identified are indivisibly linked with the concept of Common Law rights, as the former can only become understood and made incarnate through the latter.

\section{B Common law rights}

As previously discussed, it is well established that in England and Wales human rights are derived from a variety of sources. ${ }^{113}$ The rights recognised by Common Law are primarily manifested, as well as vindicated, through private law reme-dies, ${ }^{114}$ and whilst it is true that, as Corbett maintains, there is no universal or cohesive underlying theory of tort law, some overarching principles are identifi-

this right except such as is in accordance with the law and is necessary in a democratic society in the interests of national security, public safety or the economic well-being of the country, for the prevention of disorder or crime, for the protection of health or morals, or for the protection of the rights and freedoms of others.'

111 Art 9(2): 'Freedom to manifest one's religion or beliefs shall be subject only to such limitations as are prescribed by law and are necessary in a democratic society in the interests of public safety, for the protection of public order, health or morals, or for the protection of the rights and freedoms of others.' 112 Lee vMcArthur \& Ors [2016] Northern Ireland Court of Appeal 29.

113 MElliott/STierney/A Young, Human Rights Post-Brexit: The Need For Legislation? Public Law for Everyone, 8 February $2018<\mathrm{https}$ //publiclawforeveryone.com/2018/02/08/human-right s-postbrexit-the-need-for-legislation/>.

114 Parkinson v St James NHS Trust [2001] EWCA 530. 
able. ${ }^{115}$ It should be stressed that the nature and scope of Common Law rights remains a controversial topic, and there is by no means universal acceptance of the concept of free-standing rights existing independently of remedial torts, and championed by authors like Stevens. ${ }^{116}$ Nevertheless, as the Supreme Court's re-cent declarations in the R (UNISON) v Lord Chancellor case have reminded us it is impossible to deny that one key function of tort is to uphold the rule of law through the defence of individual and collective rights. ${ }^{117}$

It is often the case that, as Moreham argues, Common Law rights march in step with those conferred by the Convention and Human Rights Act, ${ }^{118}$ and as a result, it is not always necessary for judges to disentangle whether and when they are responding to a requirement imposed arising from the domestic legal setting, rather than the international instrument. Moreham was writing in the context of the right to privacy, and how breach of confidence branched out from its original ambit, of preventing disclosures of private information revealed within confidential relationships, to a far more expansive remit. The impulse from art 8 was pushing in the same direction as the organic evolution of Common Law, and consequently, the driving forces were effectively fused.

As Hartshorne ${ }^{119}$ observes, the nature of our juridical system means that Com-mon Law evolves, incrementally, and by stepping-stones. However, judges do not have the capacity to conjure solutions to perceived problems from thin air nor to spin legal gold from straw, but must work within the confines of pre-existing materials. The mere fact that they recognise a need derived from a Convention right will not, in itself, allow them to formulate a convenient response, unless there are suitable existing principles with which to work. This allows for what Phillipson terms 'weak horizontal direct effect'120 building on the earlier work of scholars like Hunt. ${ }^{121}$ In other words, courts would not give direct effect to a Convention article in the strict sense, but would allow it to mould their interpretation of Common Law. For our purposes, it is consequently reasonable to suggest that the traffic

115 V Corbett, The Promotion of Human Dignity: A Theory of Tort Law (2017) 58 Irish Jurist 121. 116 RStevens, Torts and Rights (2007).

117 R (UNISON) v Lord Chancellor [2017] United Kingdom Supreme Court (UKSC) 51 per Lord Reed paras 66-80.

118 NMoreham, Douglas and Others v Hello-the Protection of Privacy in English Private Law (2001) 64 MLR 767.

119 J Hartshorne, The Need for an Intrusion upon Seclusion Privacy Tort within English Law (2017)

46 (4) Common Law World Review 287.

120 G Phillipson, The Human Rights Act, 'Horizontal Effect' and the Common Law: A Bang or a Whimper? (1999) MLR 824.

121 MHunt, The Horizontal Effect of the Human Rights Act (1998) Public Law (PL) 423, 442. 
between both arts 8 and 9 and Common Law would incline judges towards moulding a solution from trespass if the opportunity presented itself.

Nevertheless, whilst this is an important point to appreciate, it is also vital not to imagine that the Common Law rights are fused with, subsumed within or de-rived from Convention rights (or indeed rights flowing from EU law when these may be applicable as well or instead). Significantly, in UNISON ${ }^{122}$ the Supreme Court analysed the right to access to justice, and was at great pains to stress that the Common Law right was independent from the rights generated by art 6, as well as the requirement to provide an effective remedy in respect of EU law. The Common Law right was a stand-alone concept, which would survive were the others washed away. Lord Reed even stressed that whilst the Common Law right was subject to a principle which functioned very much like proportionality, this was distinct and an example of convergent evolution by two legal frameworks. ${ }^{123}$

This is a crucial consideration in relation to the Common Law right with which we are most directly concerned for present purposes: the right to bodily integrity. As Herring and Wall convincingly demonstrate, this is a specific right recognised by the English legal framework, ${ }^{124}$ and as they note, ${ }^{125}$ Hale LJ de-scribed it as 'the first and most important of the interests protected by the law of tort'. ${ }^{126}$ This is undoubtedly true, and the reason why criminal cases are still relevant to our present discussion is that trespass to the person is such an ancient facet of our legal system that it pre-dates the separation of civil and criminal law. ${ }^{127}$

In a nutshell, the right of individuals to determine what happens to their body is a basic and long-standing principle within the English and Welsh legal sys-tem, ${ }^{128}$ and it is difficult to deny that forcing a vegan to not merely touch, but actually ingest, animal products, is a dramatic affront to their corporeal self-de-termination.

122 R (UNISON) v Lord Chancellor [2017] UKSC 51.

123 Ibid per Lord Reed para 89.

124 JHerring/JWall, The Nature and Significance of the Right to Bodily Integrity (2017)

Cambridge Law Journal (CLJ) 566, 584.

125 Ibid, 566.

126 Parkinson v St James NHS Trust [2001] EWCA 530.

127 Baker, An Introduction to Legal History (4th edn 2002) 60-63.

128 Ibid, 402-405, 472-477. 


\section{The Spanish paradigm}

So far, our discussion has revealed that the well-established right to bodily auton-omy embedded in the English and Welsh system is key to finding a satisfactory response to our core question. We now pause to consider the very different ap-proach which might emerge to a similar factual paradigm in Spain, asking how a context which understands and weighs fundamental interests differently, deals with safeguarding both bodily autonomy and freedom of belief, when it comes to the deliberate ethical contamination of food.

At the very beginning of this analysis, we should reiterate well-trodden ground, highlighting Brüggemeier's observation that there is no such thing as European tort law, and further, that the 'pigeon-hole' approach of individual torts is a feature of the Common Law tradition not manifested elsewhere. ${ }^{129}$ Further-more, we should also stress at the outset that, as Bachmaier, Gomez-Jara and Ruda demonstrate: 'the Spanish legal system positively fosters the eradication of any clear divide between tort and crime'. ${ }^{130}$

In other words, there is no hard border between these two legal territories in the Spanish model, counter intuitive though this may seem to contemporary English jurists. When it comes to crimes, offenders may be brought into the justice system either via public authorities, or at the instigation of private parties who have suffered as a result. Equally, victims may choose to use mechanisms to obtain compensation rooted in either the Criminal or Civil Code.

Consequently, there are two distinct potential routes by which a Spanish victim of ethical contamination might seek redress: 1) pursuant to art 109 of the Spanish Criminal Code; or 2) via art 1902 of the Civil Code. Whenever a criminal offence is committed and a third party has suffered harm as a result, art 109 instantly and automatically generates a right for the injured third party to bring a civil claim. It should also be noted that civil claims can also arise where no crime has been committed, but where art 1902 of the Civil Code nevertheless bites and produces extra-contractual liability. Criminal liability which injures third parties cannot exist independently of civil liability, by virtue of art 109, but there are some circumstances in which purely tortious liability does exist, and a civil action will lie even though no criminal offence has been committed.

Both the Criminal Code and the Civil Code contain relevant provisions which safeguard essential interests of individuals within the Spanish jurisdiction, in-

129 GBrüggemeier, Protection of personality rights in the law of delict/torts in Europe, in: G Brüggemeier/AColombi Ciacchi/ POCallaghan (eds), Personality Rights in European Tort Law (2010) 5. 130 LBachmaier/C Gomez-Jara/ARuda, Blurred Boundaries in Spanish Tort and Crime, in: M Dy-son (ed), Comparing Tort and Crime: Learning Across Legal Systems (2015) 225. 
cluding the two with which we are concerned here: freedom of belief and bodily autonomy. As is the case in England and Wales, and indeed most other paradigms, the underlying rationale for a law is not always stated explicitly in its text. Nevertheless, as we shall see in our discussion, the wording and effect of the pro-visions in question make it clear that protection of these interests is at least one part of their ambit. For the sake of clarity, we will consider liability arising from the Criminal Code first, before moving on to possible actions brought using the Civil Code.

\section{A Article 109 Criminal Code}

As stated, this provision gives persons who are harmed by the criminal behaviour of another the right to bring an action for compensation. ${ }^{131}$ Consequently, in situations where in the UK paradigm civil and criminal liability would run in parallel, for example, where the defendant launches an unprovoked physical assault on the victim claimant, in Spain civil liability arises directly out of the criminal act or omission. Furthermore, there is scope for relatives of the primary victim and also third parties who have been affected to bring an action. ${ }^{132}$ This caveat is extremely important, as it would circumvent some of the difficulties which arise in an English and Welsh context, where the purchaser of food might have a contractual remedy, but others who consumed it would not have this recourse.

Article 109 functions as a piggy-back provision, and requires a criminal of-fence to be present in order for it to be engaged. This overview of the potential articles which might be triggered in this context reveals a very different focus between the English and Spanish systems in the conception and protection of bodily autonomy and freedom of belief. There is no parallel concept to common assault in Spanish criminal law, and touching another person in a non-sexual way which causes no physical harm is not an offence, meaning that art 109 can-not bite merely for non-consensual, intentional touching. We must, consequently, consider what kind of substantive provisions might apply in the scenarios we are considering, opening the door to an art 109 claim.

The first possibility is art 282 of the Spanish Criminal Code, which criminalises the making of false claims about goods or services, where these cause harm to customers. This harm need not be material or economic, and could, as a result, include the distress caused by the realisation of having consumed food which

131 Ley Orgánica 10/1995, de 23 de noviembre, del Código Penal (Penal Code) art 109.1. 132 Penal Code art 113. 
violated personal beliefs or ethics. ${ }^{133}$ Another similar, but distinct, possibility would be art 363, which deals with the trading in comestibles which are harmful to health. The thrust of this article concerns food hygiene, and it might be challenging to interpret it as covering products which were not physically toxic, but it does expressly include the traffic of 'corrupted' goods. ${ }^{134}$ Bearing this in mind, the question would be whether a court would be prepared to interpret 'corrupted' to encompass doctrinal, rather than physical corruption.

It should be highlighted that these provisions are aimed primarily at protecting individuals from bodily harm, rather than defending corporeal autonomy. Nonetheless, if an expansive definition of harm is adopted, victims would benefit from fairly robust protection afforded by art 109, and possibly also art 282 of the same Code. Given, as we have noted, that there is also a provision which brings injured third parties within these parameters, the complexity brought about by privity of contract in a UK setting does not arise. In addition, art 120 imposes something akin to vicarious liability, rendering employers and others accountable in civil law for the crimes of their workers or agents. So, a business owner could not escape the obligation to pay compensation by arguing that their employees perpetrated the contamination, although, as with any form of vicarious liability, there will be scope for uncertainty about when an individual was or was not acting for another. ${ }^{135}$

Nevertheless, there remains the troubling issue of malicious individuals who are not in any kind of commercial relationship with the victims. What about the stranger who, in an opportunistic or perhaps even premeditated fashion, targets someone for this form of abuse, motivated by either personal or collective hatred? It is here that the difference in the underlying values of the two systems is most marked, and arguably too, this is the most likely scenario in the ordinary course of events.

Generally speaking, businesses are keen not to cause dissatisfaction, much less distress, to their customers. ${ }^{136}$ So, we must focus on the protection of indivi

133 Penal Code art 110. 3.

134 Penal Code art363.3 'Traficando con géneros corrompidos'.

135 This differing approach towards making third parties legally liable for criminal acts is a clear out working of the fusion between tort and crime in the Spanish paradigm. Making an innocent party responsible for the crime of another would be anathema to most Common Law commentators, but the intermingling of public and private wrongs and redress makes this less problematic.

136 Aside from the Goodman case, instances of deception by commercial enterprises have usually arisen from cynical attempts to increase profit margins by sourcing cheaper meat. 'What are the chances your lamb curry is actually beef?' The Telegraph 9 February $2015<$ https://www.tele graph.co.uk/news/shopping-and-consumer-news/11401670/What-are-the-chances-your-lamb-c urryis-actually-beef.html>. 
duals from mischievous interference by strangers, and in this regard, the most promising provisions in the Spanish setting are targeted not at bodily integrity, but at freedom of belief. As previously stated, the Spanish Criminal Code does not have a conception of bodily integrity which imposes a general prohibition on touching in the absence of injury, a sexual element or associations with domestic abuse ${ }^{137}$ and, consequently, there is nothing directly analogous to common as-sault in criminal law and battery in the English and Welsh tortious context. As a result, outside of the commercial sphere, we are driven to look at provisions protecting religious freedom if we are to find a route to claim under art 109.

In contrast with bodily autonomy, where the English system takes a more expansive view of protecting the interest, the Spanish setting adopts a more focused approach to safeguarding and protection in relation to freedom of reli-gion. ${ }^{138}$ Whilst the English framework tends towards showing a supportive stance to the practice of religion and manifestation of conscience, ${ }^{139}$ it does not have any overarching provision criminalising impeding such activities. In certain circumstances, a particular form of hate crime may be applicable, ${ }^{140}$ but molesting or hindering a person or group of people from expressing their beliefs is not pro-scribed as an offence in its own right.

This position is striking when juxtaposed with the Spanish Criminal Code, which specifically outlaws impeding religious practice of others, particularly via arts 522$523,{ }^{141}$ and it is difficult to find many more unpleasant and dramatic interferences than deliberately spiking a person's food with material known to be abhorrent to their belief system. Thus the Jewish, Muslim or Hindu victim of this

137 Penal Code arts 147-155.

138 See S Cañamares, Libertad Religiosa e Igualdad: Algunos Supuestos Discutidos (2011) Revista General de Derecho Canónico y Derecho Eclesiástico del Estado. This author carries out an interesting analysis of the relationship between religious freedom and the principle of equality.

139 J Garcia Oliva/H Hall, Religion, Law and the Constitution: Balancing Beliefs in Britain (2017) chs $2-3$. Independently of art 9 , the Common Law has also developed in a way which protects free-dom of belief and conscience. Historically, the members and purposes of the Church of England were favoured, but when this became politically and philosophically unacceptable in the course of the nineteenth century, the general trend was to address inequality by widening the reach of legal benefit. If Anglican religion needed to be accommodated and respected, then firstly other forms of Christianity, and latterly other faiths also had to be accorded the same treatment. From here on it was a natural step to recognise non-religious matters of conscience, for example, granting pacifists exemption from conscription, regardless of whether their objection lay in faith, politics or philoso-phy, eg Military Service Act 1916.

140 See eg the Public Order Act 1986 (as amended).

141 Penal Code art522f. 
kind of behaviour has a clearer and more sharply defined path to a remedy than is currently the case in England and Wales.

Regrettably though, there is a sharp sting in the tail. As the work of MartínezTorrón demonstrates, ${ }^{142}$ these provisions undoubtedly cover atheists, agnostics and humanists, and this position is well supported by case law. ${ }^{143}$ However, it is uncertain whether those adopting veganism for ethical reasons not tied to religion could access this protection. The text of the Criminal Code itself suggests not, as the reference to religious beliefs is clear. If tested, a court might nevertheless be prepared to construe these provisions as covering other convictions under the ambit of art 9, but it would be difficult to suggest any obligation on the part of a Spanish court to do this, flowing from domestic, EU equality law, ${ }^{144}$ or the provisions of the ECHR. ${ }^{145}$ Neither the wording of the legal instruments nor judicial pronouncements in case law imply that legislation targeted at protecting religious freedom must encompass all forms of freedom of conscience.

Another alternative avenue might be potentially via art 173 , which deals with 'torturas y otros delitos contra la integridad moral' (torture and other crimes against moral integrity'). ${ }^{146}$ This could, theoretically, be applied in conjunction with the provisions of art 22.4, which lists hatred or prejudice based on a number of characteristics, including religion or belief, as an aggravating circumstance of a criminal offence. ${ }^{147}$ The problem, however, is that the threshold between strangers is intended to be a very high one. The law distinguishes between torture, and other forms of degrading treatment, and only torture is criminalised between strangers, whilst lesser forms of abuse require a concrete, pre-existing relation-ship with a person or a place, applying in an employment or domestic context. Deeply unpleasant and distressing though tampering with a person's food undoubtedly is, it is hard to imagine that it could be construed as 'torture', when this concept is explicitly distinguished from degrading treatment more generally. Consequently, in our view, these provisions also would not avail.

All in all, it appears that whilst religiously motivated vegans are well served by these provisions, those driven by ethical concerns may struggle to access the

142 J Martínez-Torrón, Spain, in Religion in the International Encyclopaedia of Laws (2010) 66.

143 STC 46/2001, STSJ Madrid de 30 marzo de 2012; STSJ Castilla y León, 14 Dic 2009.

144 Directiva 2004/83/CE; STJUE, Gran Sala de 5 sept 2012.

145 Campbell v Cousins v UK [1982] ECHR 1.

146 G Martinez Mora, Comentario al Artículo 173 del Código Penal (2019) VLex España 246-256.

147 MGrigolo, Human Rights and Cities: The Barcelona Office for Non-Discrimination and Work for Migrants, in: Patricia Hynes et al (eds), Sociology and Human Rights, New Engagements (2011) 95. 
protection in the Spanish context. Furthermore, individuals who choose to be vegan for the benefit of their health will clearly be excluded completely.

Therefore, if a malicious individual contaminated a non-religious vegan's food with meat juices, and it did them no harm, the criminal law would not readily provide redress. Would the Civil Code by any more promising?

\section{B Article 1902 of the Civil Code}

As we have discussed, this second avenue applies to situations where the Crim-inal Code does not extend. Article 1902 is broadly drafted, and simply requires a defendant to pay reparation where he or she has caused damage to another party, either by fault/intention or negligence. The text of the Civil Code does not itself define what is meant by damage, ${ }^{148}$ but as Medina Alcoz argues, case law has demonstrated that it includes what within the Spanish system is termed 'moral damage'. ${ }^{149}$ Unfortunately, as we have already seen, and as authors like Sánchez González ${ }^{150}$ and also DíezPicazo $^{151}$ eloquently demonstrate, the ambit of moral damage is by no means easy to pin down in the Spanish context. Moreover, it is undeniable that the concept continues to evolve, both in Spain itself and other settings which have been influenced by this paradigm, and the almost inevitable consequence of this is its wide ambit. ${ }^{152}$

The inclusion of damage for emotional distress is not per se problematic and, although no precedent exists, it would seem reasonable to assert that feelings of trauma arising from a deliberate and malicious interference with the victim's liberty of conscience and bodily integrity could in principle come within the auspices of art 1902. Nevertheless, the extent of its reach, and the level of compensation which would be awarded in this novel context are by no means clear, and it is difficult to escape the conclusion that whilst the position of those following religiously determined diets is well protected, the safeguards on offer for other victims of ethical contamination are weaker in comparison. Ultimately, the more

148 MMartín-Casals/J Ribot, Spain, in: B Winiger et al (eds), Digest of European Tort Law, vol2: Essential Cases on Damage (2011) 1/10 no $1 \mathrm{ff}$.

149 M Medina Alcoz, Compensation for Moral Damages in Spanish Law, National Road Traffic Conference (5th edn 2010) 3. Eg, Tribunal Superior de Justicia de Andalucía, Sevilla (Sala de lo Social, Sección 1aㅡ) Sentencia num. 1675/2017 de 1 junio; Tribunal Superior de Justicia de Madrid, (Sala de lo Contencioso-Administrativo) Sentencia num. 662/2016 de 22 diciembre.

150 M· Sánchez González, El Daňo Moral: Una aproximación a su configuración jurídica (2006) Revista de Derecho Privado 90, 27

151 L Díez-Picazo, Derecho de Daňos (1999) 324.

152 G Pérez Fuentes, El Daňo Moral en Iberoamérica (2006). 
conservative interpretation of bodily autonomy in Spain is one of the reasons for this and, combined with the failure of the Criminal Code to place non-religious matters of conscience on an equal footing with religious ones, vegans motivated by factors other than faith are comparatively exposed.

\section{Conclusion}

These gaps in the Spanish framework provide additional support for the idea that focusing on bodily autonomy in the English context has much to commend it. Of the two interests at play where ethical contamination is concerned, religious/ ideological freedom and bodily autonomy, the latter has the significant advantage of being universally applicable. By placing emphasis on the idea that all persons have a nonnegotiable right to determine what does or not does not enter their body, complicated debates about access to protection can be avoided. The features which we have identified in our Spanish analysis lead us to propose that trespass should be the natural and obvious route to follow in the English and Welsh paradigm.

A disturbing incident from the United States demonstrates the advantages of this approach. A teenager baked her grandmother's ashes into cookies, and fed the contaminated biscuits to fellow students, who had no clue that they were consuming human remains. ${ }^{153}$ Authorities were unsure of what criminal charges, if any, might apply and it is not yet clear whether any civil action might be brought. ${ }^{154}$ Nevertheless, this is a clear illustration of how people might feel distressed and violated at unwittingly consuming a substance which was physically harmless, even if they did not identify as vegan or with a specific religious tradition.

Taken altogether, the combined weight of arts 8 and 9, alongside the independent Common Law rights discussed, suggest a very powerful impetus to push tort law in the direction of extending trespass to cover this kind of situation. It is the poster tort for protecting bodily self-determination.

There is ample evidence from case law that an indirect application of force can amount to a battery in appropriate circumstances, and therefore, orchestrating a situation in which a person inadvertently touches and consumes a sub-

153 California student baked grandma's ashes into cookies, BBC News 17 October $2018<$ https:// www.bbc.co.uk/news/world-us-canada-45888446>.

154 California student reportedly served cookies baked with grandma's ashes to students, Fox News, 16 October $2018<$ https://www.foxnews.com/us/california-student-reportedly-served-cook ies-cookedwith-grandmas-ashes>. 
stance they would not wish to be in contact with, could be construed as trespass without contorting existing principles to snapping point.

This outworking of a Common Law right through an established cause of action would also vindicate the key Convention rights which are engaged, and would also be in harmony with the respect which the legal framework shows for individual freedom of belief and conscience in the English and Welsh context. Whilst none of these forces would enable a court to break the chain of legal development and radically remodel trespass, they would be more than sufficient to push it further along its current trajectory. In our view, this would be a logical and desirable path to take in safeguarding individuals from molestation, in addition to upholding individual dignity and autonomy.

Endnote: We are indebted to Santiago Cañamares, Simon Deakin, David Feldman, John Hart-shorne, Manuel Horta, Thomas Lewis, Jeff Murray, Javier Martínez Torrón, Dawn Oliver, María de la Paz Sánchez and Alison Young for their comments and feedback in the production of this article. Any infelicities, of course, are entirely are own. 